\title{
THE IMPROVING OF STUDY RESULT IN SOCIAL SCIENCE SUBJECT BY USING DISCOVERY LEARNING MODEL FOR STUDENT IN CLASS VII-3 AT JUNIOR HIGHT SCHOOL NUMBER ONE SUB-DISTRICT OF LUAK
}

\author{
Jusni \\ e-mail:jusni27@gmail.com
}

\begin{abstract}
The purpose of this research was to analyze the improvement of study result of a social science subject in class VII-3 student at junior high school number 1 subdistrict of Luak. This research started with pra-cycle and it was held by using the classroom action research method. This research was dividing into two cycles, while each cycle was contained planning, action, reflection, and evaluation. This research was held from September to November 2019 in VII-3 Class of Junior high School number one One sub-District of Luak. The data was processed in every cycle and then it was analyzed in percentage. The result of this research proves that the competence percentage of study results and the result of the average score of the student improved. While in pre-cycle, the average score of the student was 65,17 with $35 \%$ of competencies. Then, the result improved in the first cycle with the average score of the student was 74,31 with 83,47 of competencies. And it keeps improving for the second cycle with an average score up to 83,47 with 89,66\% of competencies for the student result. Therefore, the result of this research was proven that the process of teaching with the Discovery Learning model can improving the result of the social science subject of the student.
\end{abstract}

Key word: Discovery Learning, Social Science Subject, Study Result

\begin{abstract}
ABSTRAK
Artikel penelitian ini bertujuan untuk menganalisis peningkatan hasil belajar IPS terhadap peserta didik di kelas VII-3 SMP Negeri 1.Kec. Luak. Penelitian ini dimulai dengan prasiklus dan dilaksanakan mengunakan metode Penelitian Tindakan Kelas yang terdiri dari dua siklus, dimana setiap siklus terdiri dari; perencanaan, tindakan, refleksi, dan evaluasi. Penelitian ini dilaksanakan pada bulan September sampai dengan November 2019 di kelas VII-3 SMP Negeri 1 Kec.Luak. Data diolah pada setiap siklus kemudian dianalisis menggunakan presentase. Hasil yang diperoleh dari penelitian ini adalah terjadi peningkatan pada hasil belajar peserta didik berupa nilai rata-rata kelas dan persentase ketuntasan. Pada prasiklus didapatkan rata-rata ketuntasan peserta didik pada mata pelajaran IPS sebanyak $35 \%$ dengan nilai rata-rata 65,17 . Kemudian meningkat pada siklus I dengan persentase ketuntasan menjadi 55,17 \% dengan nilai rata-rata 74,31 dan mencapai ketuntasan pada siklus II dengan nilai rata-rata 83,47 dengan persentase ketuntasan mencapai target sebesar 89,66\%.Kesimpulan yang diperoleh dari penelitian ini adalah pelaksanaan belajar mengajar dengan menggunakan model pembelajaran Discovery Learning dapat meningkatkan hasil belajar IPS peserta didik.
\end{abstract}

Kata Kunci: Discovery Learning, Ilmu Pengetahuan Sosial, Hasil Belajar

\section{PENDAHULUAN}


Pembelajaran Ilmu Pengetahuan Sosial ( IPS ) di SMP terdiri dari mata pelajaran Geografi, sosiologi, ekonomi dan sejarah. Kalau dipahami dengan baik, mata pelajaran ini secara tidak langsung akan memberikan kontribusi yang sangat penting dalam pembentukan karakter peserta didik di masa yang akan datang. Hal ini sesuai dengan tujuan pendidikan Nasional yaitu berkembangnya potensi peserta didik agar menjadi manusia yang beriman dan bertakwa kepada Tuhan Yang Maha Esa, berakhlak mulia, sehat, berilmu, cakap, kreatif,mandiri dan menjadi warga Negara yang demokratis serta bertanggung jawab ( UU nomor 20 tahun 2003 tentang sistem Pendidikan Nasional ) pemahaman itu timbul apabila banyak membaca dan paham apa yang di bacanya.

Pendekatan pembelajaran diarahkan pada upaya mengembangkan kemampuan peserta didik dalam mengelola perolehan belajar (kompetensi). Dengan demikian proses pembelajaran mengacu kepada bagaimana peserta didik belajar secara aktif. Serta dapat memperoleh hasil belajar yang memuaskan.

Namun, berdasarkan hasil penilaian harian 1 pembelajaran IPS pada KD 3:1, di kelas VII,3 dari 29 orang peserta didik yang mengikuti penilaian harian, hanya 10 orang peserta didik yang memiliki hasil belajar di atas KKM (75). Adapun persentase ketutasan pada kelas tersebut hanya 35\%. Sedangkan target persentase ketuntasan yang diharapkan pada peserta didik minimal $80 \%$.

Untuk itu, guru perlu memiliki beberapa prinsip mengajar yang mengacu pada kemampuan peningkatan internal peserta didik dalam merancang strategi pembelajaran yang memungkinkan peserta didik mampu mencapai kompetensi secara penuh, utuh, dan kontekstual.

Oleh karena itu, peneliti tertarik melakukan penelitian Tindakan Kelas dengan menggunakan model pembelajaran Discovery Learning. Karena model Discovery Learning mengharuskan peserta didik fokus terhadap pembelajaran yang sedang berlansung mulai dari mengamati, bertanya, mengumpulkan data, mengasosiasi sampai ke menyimpulkan dan mempresentasikan hasil diskusinya, sehingga peserta didik belajar lebih aktif dan diharapkan mampu meningkatkan hasil belajar. Sehingga target ketuntasan belajar tercapai.

\section{METODOLOGI}

Penelitian Tindakan Kelas ini dilaksanakan di SMPN 1 Kecamatan Luak pada Kelas VII,3 Semester 1 TP. 2019/2020. Penelitian tindakan kelas dimulai dari tanggal 5 September 2019 sampai dengan tanggal 7 November 2019.

Subjek penelitian adalah peserta didik kelas VII,3 yang berjumlah 29 orang, yang teridiri dari 15 orang laki-laki dan 14 orang perempuan. Model Pembelajaran yang digunakan model pembelajaran discovery learning.

Adapun teknik pengumpulan data dilakukan dengan observasi langsung terhadap subjek penelitian dengan menggunakan lembar observasi. Kemudian hasil pengamatan akan dianalisis dengan melihat peningkatannya dalam setiap siklus, menggunakan catatan lapangan, lembar observasi dan hasil tes.

Data pengisian lembar observasi aktivitas peserta didik akan dianalisis dengan cara kuantitatif dan kualitatif. Analisis data kuantitatif menggunakan 
rumus sederhana dan analisis data kualitatif diambil dari hasil catatan lapangan dan lembar observasi.

Hasil belajar diolah dengan cara menganalisis hasil tes untuk melihat ketercapaian KKM. Peserta didik dapat dikatakan telah mencapai KKM apabila nilai IPS telah mencapai $\geq 75$. KKM yang ditetapkan di SMPN 1 Kecamatan Luak adalah 75. Dalam penelitian ini diharapkan jumlah peserta didik yang telah mencapai KKM adalah $\geq 80 \%$.

Untuk mencapai KKM ssesuai persentase yang telah ditetapkan digunakan rumus :

$\mathrm{NT}=\frac{\mathrm{ST}}{\mathrm{N}} \times 100 \%$

Keterangan :

$\mathrm{NT}=$ persentase banyaknya peserta didik yang mencapai KKM

$\mathrm{ST}=$ jumlah peserta didik yang mencapai KKM

$\mathrm{N}=$ jumlah seluruh peserta didik dalam kelas

Selanjutnya kelas dikatakan telah berhasil apabila persentase banyaknya peserta didik yang mencapai KKM $\geq 80 \%$.

\section{HASIL PENELITIAN DAN PEMBAHASAN}

\section{A. HASIL PENELITIAN}

Hasil pengamatan terhadap hasil belajar peserta didik selama pelaksanaan pembelajaran pada prasiklus, siklus 1 dan siklus 2 mengalami Peningkatan. Hasil belajar peserta didik dalam proses pembelajaran yang diperoleh pada prasiklus, siklus 1 dan siklus 2 dengan model pembelajaran discovery learning pada mata pelajaran IPS di kelas VII,3 SMPN 1 Kecamatan.Luak.

Tabel 1: Persentase Peningkatan Hasil Belajar Peserta Didik berdasarkan nilai rata-rata kelas

\begin{tabular}{|l|c|c|c|}
\hline \multirow{2}{*}{\multicolumn{1}{|c|}{ Kriteria }} & \multicolumn{3}{|c|}{ Siklus } \\
\cline { 2 - 4 } & Prasiklus (\%) & $1(\%)$ & $2(\%)$ \\
\hline Tuntas & $35 \%$ & $55,17 \%$ & $89,66 \%$ \\
\hline Tidak Tuntas & $65 \%$ & $44,83 \%$ & $10,34 \%$ \\
\hline Jumlah & $100 \%$ & $100 \%$ & $100 \%$ \\
\hline
\end{tabular}




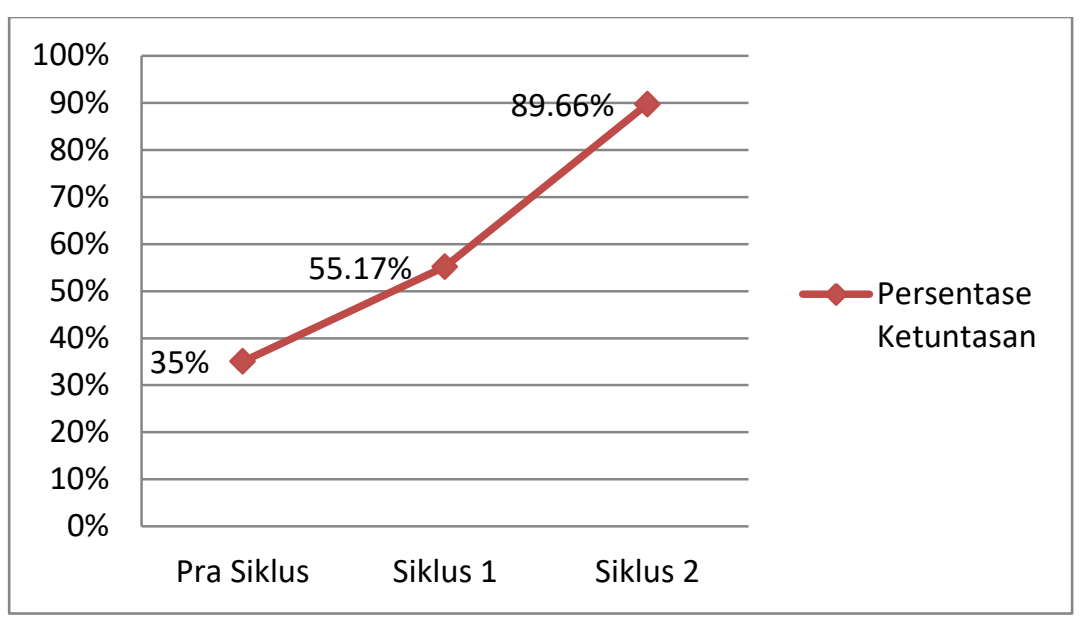

\section{Grafik.1 Peningkatan Persentase Ketuntasan Hasil Belajar Peserta Didik}

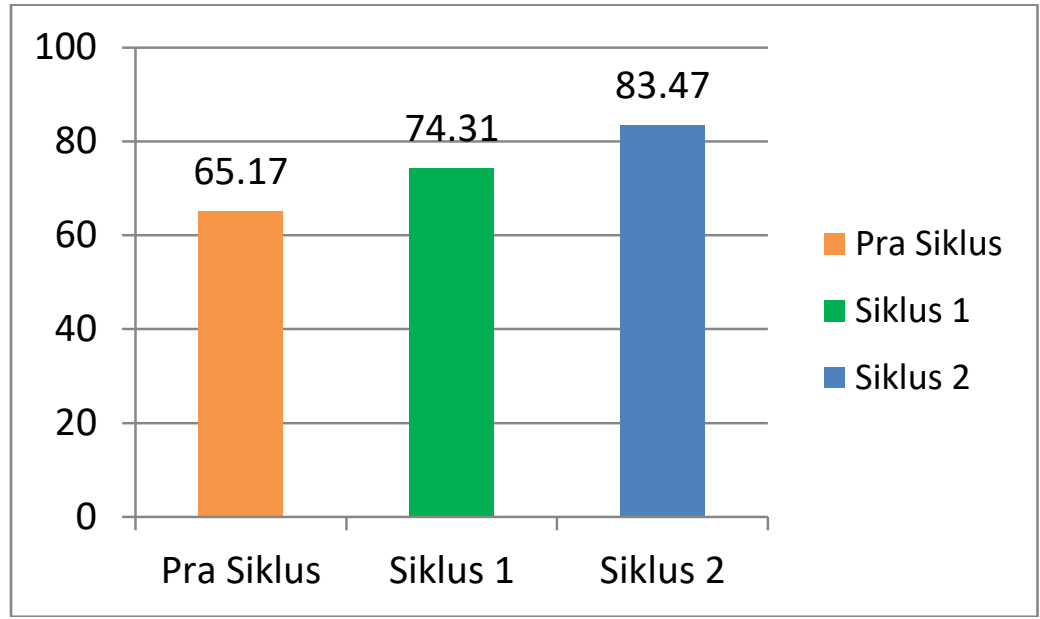

Grafik.2 Peningkatan Nilai Rata-Rata Hasil Belajar Peserta Didik

Berdasarkan tabel.1 dan grafik.1 di atas terlihat bahwa persentase hasil belajar peserta didik mengalami peningkatan dari ketuntasan yang hanya $35 \%$ pada prasiklus, meningkat menjadi menjadi $55,17 \%$ pada siklus I dan mencapai persentase ketuntasan pada siklus II sebesar $89,66 \%$.

Berdasarkan grafik.2 di atas juga dapat dilihat bahwa nilai rata-rata kelas pada hasil belajar juga mengalami peningkatan. Dari nilai rata-rata 65,17 pada prasiklus, meningkat menjadi 74,31 pada siklus I dan mencapai KKM pada siklus II dengan nilai rata-rata 83,47.

Berdasarkan kriteria ketuntasan yang mengatakan bahwa jika $80 \%$ peserta didik telah mendapatkan nilai minimal yang ditetapkan (KKM) yaitu $\geq 75$ maka dikatakan kelas tersebut sudah tuntas secara klasikal dengan persentase yang dapat dilihat $89,66 \%$. Indikator keberhasilan telah tercapai yaitu $80 \%$. Sedangkan nilai rata-rata peserta didik adalah 74,31 pada siklus 1 dan meningkat pada siklus 2 dengan nilai di atas KKM yaitu 83,47. 


\section{KESIMPULAN DAN SARAN}

\section{A. Kesimpulan}

Berdasarkan hasil penelitian dan refleksi yang telah dilakukan dapat diambil beberapa kesimpulan sebagai berikut :

1. Penggunaan model pembelajaran Discovery Learning dapat meningkatkan kesempatan peserta didik di kelas VII.3 terlibat aktif dalam pembelajaran, seperti bekerjasama, berbagi informasi, berani mengemukakan ide-ide baru melalui presentasi.

2. Penggunaan model pembelajaran Discovery Learning dapat Meningkatkan hasil belajar IPS pada peserta didik kelas VII.3 SMPN.1 Kecamatan Luak dengan peningkatan nilai rata-rata hasil belajar. Dari nilai rata- rata hasil belajar pada prasiklus 65,17 meningkat menjadi 74,31 pada siklus I dan meningkat kembali pada siklus II dengan rata-rata 83,47.

3. Penggunaan model pembelajaran Discovery Learning dapat meningkatkan persentase ketuntasan pembelajaran IPS peserta didik kelas VII.3 SMPN.1 Kecamatan Luak dengan persentase ketuntasan $35 \%$ pada prasiklus, meningkat menjadi $55.17 \%$ pada siklus I dan meningkat menjadi $89,66 \%$ pada siklus II.

\section{B. Implikasi}

Pentingnya pemahaman guru dalam menerapkan model-model pembelajaran yang sesuai dengan karakteristik materi yang dipelajari peserta didik, dan dapat menjadi salah satu cara dalam mengatasi kesulitan guru dalam mengajarkan IPS. Dengan menggunakan model discovery learning dapat lebih mengarahkan peserta didik untuk lebih aktif dalam pembelajaran sehingga hasil belajar juga meningkat.

\section{Saran}

Berdasarkan simpulan dan implikasi pada penelitan tindakan kelas ini, peneliti memberikan saran :

1. Disarankan kepada guru untuk membuat pembelajaran lebih menarik dan menyenangkan terutama dalam mempelajari pelajaran IPS

2. Guru sebaiknya mencoba model model pembelajaran yang membuat peserta didik lebih aktifd dalam belajar sehingga peserta didik dapat mengeksplor kemampuannya.

\section{DAFTAR PUSTAKA}

Ananda Azwar. 2003. Membangun Belajar Aktif Dalam Interaksi Belajar Mengajar di Dalam Kelas. Padang. Jurnal Pembelajaran.

Djamrah Syaiful Bahri. 2000. Guru dan Anak Didik dalam Interaksi Edukatif. Jakarta. Rineka Cipta

Jurnal Edukasi Dinas Pendidikan Provinsi Sumatera Barat No.1 Volume 3 Tahun 2019 ISSN 2549-9177. Padang 
Muhammad Numan Soemantri. 2001. Menggagas Pembaharuan Pendidikan IPS. Bandung: Remaja Rosdakarya

Permendikbud No.21 Tahun 2016 Tentang Standar Isi.

Permendikbud No. 22 Tahun 2016 Tentang Standar Proses.

Permendikbud No. 23 Tahun 2016 Tentang Standar Penilaian..

Suharsimi Arikunto. 2010. Prosedur Penelitian. Jakarta: Rieneka Cipta

Sukmadinata Nana Syaodih.2010. Metode Penelitian Pendidikan. Bandung. Remaja Rosdakarya. 